\title{
SpraWa Al MaHdiego PRZED MiędzynarodoWyM TRYbunaŁeM KarnyM: PRZELOMOWY WYROK CZY STRACONA SZANSA?
}

\section{Wprowadzenie}

Akty niszczenia zabytków kultury towarzyszyły konfliktom zbrojnym od zarania dziejów. Były one podyktowane koniecznością wojskową, względami ekonomicznymi, jednakże głównie miały one na celu zniszczenie kultury przeciwnika, jego upokorzenie i uniemożliwienie przekazania dziedzictwa kulturowego następnym pokoleniom. Choć wydawać by się mogło, że obecnie prawo międzynarodowe w dostateczny sposób chroni zabytki kultury, to właśnie chęć „kulturowej czystki”1, eliminacja śladów kulturowych i „duchowe” upokorzenie przeciwnika stało się głównym celem ataków grup ekstremistycznych na całym świecie, których działalność wywołuje oburzenie opinii publicznej. Z tym większą uwagą zatem należy przyjrzeć się wyrokowi wydanemu przez Międzynarodowy Trybunał Karny (MTK) w 2016 r. w sprawie Ahmada Al Faqi Al Mahdiego. Choć nie jest to pierwszy wyrok trybunału międzynarodowego poruszający kwestie niszczenia dóbr kulturalnych ${ }^{2}$, jest to pierwsza

* Mgr, Uniwersytet Śląski; e-mail: karolina.prazmowska@us.edu.pl, ORCID ID: https:/ / orcid.org/0000-0002-3080-6924.

1 United Nations Educational, Scientific and Cultural Organization (UNESCO), Reinforcement of UNESCO's Action for the Protection of Culture and the Promotion of Cultural Pluralism in the Event of Armed Conflict, 38 C/49, 2 November 2015 https:/ / unesdoc. unesco.org/ark:/48223/pf0000235186 [dostęp: 3.02.2020 r.].

2 Do kwestii niszczenia dóbr kultury w trakcie konfliktów zbrojnych odniósł się między innymi Międzynarodowy Trybunał Karny dla byłej Jugosławii (United Nations International Criminal Tribunal for the former Yugoslavia, ICTY) w sprawach: Prosecutor v. Miodrag Jokić, 
sprawa oparta na naruszeniu jednego tylko artykułu Statutu Rzymskiego $^{3}$ - art. 8 ust. 2 lit (e) (iv) - uznającego za zbrodnię wojenną zamierzone kierowanie ataków na budynki przeznaczone m.in. na cele religijne, edukacyjne, artystyczne, pomniki historyczne, szpitale oraz miejsca, gdzie gromadzeni są ranni i chorzy, pod warunkiem, że nie są one celami wojskowymi. Jest to też najkrótszy, trwający zaledwie trzy dni, proces w historii MTK, jako że oskarżony, na mocy art. 65 Statutu Rzymskiego, przyznał się do winy. Wyrok ten, choć niepozbawiony kontrowersji, świadczy o znaczeniu, jakiego na arenie międzynarodowej nabiera dziedzictwo kulturowe, zarówno w jego materialnej, jak i niematerialnej formie oraz prawa kulturalne, których wartość przez wiele lat była marginalizowana.

\section{Ewolucja ochrony kultury $\mathrm{w}$ prawie międzynarodowym}

Początki ochrony kultury wiążą się nierozerwalnie z konfliktami zbrojnymi. Przykładów burzenia i łupienia zdobytych miast nie brakowało ani w starożytności, ani w średniowieczu oraz w wiekach późniejszych, nie wyłączając $X X$ w. Jednak owym haniebnym praktykom od zawsze towarzyszyły głosy krytyki, czego dowodem mogą być chociażby teksty Polibiusza i Cycerona, w których potępiali oni wszelką grabież i zniszczenia dzieł sztuki ${ }^{4}$. W średniowiecznej Europie etos rycerski chronił kościoły oraz klasztory. Idee ochrony dóbr kultury odnaleźć można także w pochodzącej z VII w. instrukcji kalifa Abu Bakr Siddiq skierowanej do żołnierzy przed podbojem Syrii i Iraku oraz w prawie hinduskim, rozróżniającym cele wojskowe, które mogły stać się przedmiotem ataku oraz cele nie wojskowe, w stosunku do których atak był zakazany. Natomiast w XVI w. japońscy władcy feudalni zaczęli wydawać instrukcje wojskowe zwane sei-satu, zakazujące swoim oddziałom ataków na świątynie

No IT-01-42/1-S, Judgement of 18 March 2004, https:/ / www.icty.org/en/case/miodrag jokic [dostęp: 3.02.2020 r.] oraz Prosecutor v. Dario Kordić \& Mario Čerkez, No IT-95-14/2-T, Judgement of 26 February 2001, https://www.icty.org/en/case/kordic_cerkez [dostęp: 3.02.2020 r.].

3 Rzymski Statut Międzynarodowego Trybunału Karnego, sporządzony w Rzymie dnia 17 lipca 1998 r., Dz. U. z 2003 r. Nr 78, poz. 708 (dalej: Statut Rzymski).

4 Zob. S.E. Nahlik, Grabież dzieł sztuki. Rodowód zbrodni międzynarodowej, Wrocław 1958, s. 75-78. 
i miejsca kultu. Idea ochrony dóbr kulturalnych stała się również przedmiotem rozważań przedstawicieli doktryny doby renesansu. Emerich de Vattel, wysunął zasadę poszanowania sanktuariów, grobowców i innych budowli o znaczeniu historycznym i kulturowym ${ }^{5}$, a celowe niszczenie dóbr kulturalnych, niepodyktowane osiągnięciem korzyści wojskowej, uważał on za "bezmyślne zaprzepaszczenie elementów ogólnoludzkiej kultury" ${ }^{\prime \prime}$. Pierwsze akty normatywne regulujące - jednakże w szczątkowy jeszcze sposób - ochronę dóbr kultury są efektem XIX-wiecznej kodyfikacji prawa wojennego. Wiodące znaczenie w tym względzie posiadały przepisy tzw. Instrukcji Liebera („Instrukcje dla dowództwa armii Stanów Zjednoczonych w polu") z 1863 r., opracowane przez Francisa Liebera na prośbę prezydenta Abrahama Lincolna7. Pierwszym dokumentem międzynarodowym, przewidującym ochronę dóbr kultury była międzynarodowa deklaracja dotycząca praw i zwyczajów wojennych ${ }^{8}$, przyjęta w Brukseli w 1874 r. ${ }^{9}$ Mimo iż deklaracja brukselska nie jest dokumentem wiążącym prawnie, stała się ona niewątpliwą inspiracją dla postanowień II konwencji haskiej z 1899 r., normującej zwyczaje i prawa podczas wojny lądowej, oraz IV konwencji haskiej z 1907 r., dotyczącej sposobu prowadzenia wojny na lądzie, w zakresie odnoszącym się do dóbr kultury. Choć konwencje haskie nie stworzyły jednolitego systemu ochrony dóbr kultury, były one istotnym krokiem na drodze do stworzenia takiego systemu. Zarówno II konwencja haska z 1899 r., jak i IV konwencja haska z 1907 r.,

5 Zob. K. Sałaciński, Dziedzictwo kultury w konfliktach zbrojnych - prawo, praktyka, nowe wyzwania, [w:] E. Mikos-Skuza, K. Sałaciński (red.), Ochrona dziedzictwa kultury w czasie konfliktów zbrojnych w świetle prawa międzynarodowego i krajowego. 60-lecie konwencji haskiej i 15-lecie jej Protokotu II, Warszawa 2015, s. 18-19.

6 Zob. F. Bugnion, The Origins and Development of the Legal Protection of Cultural Property in the Event of Armed Conflict. 50th anniversary of the 1954 Hague Convention for the Protection of Cultural Property in the Event of Armed Conflict, International Committee of the Red Cross (ICRC), https://www.icrc.org/eng/resources/documents/article/other/65shtj. htm\#a1 [dostęp: 20.05.2018 r.].

7 Zob. H. Schreiber, Konwencja o ochronie dóbr kulturalnych w razie konfliktu zbrojnego wraz z Regulaminem wykonawczym do tej Konwencji oraz Protokót o ochronie dóbr kulturalnych w razie konfliktu zbrojnego, [w:] K. Zalasińska (red.), Konwencje UNESCO w dziedzinie kultury. Komentarz, Warszawa 2014, s. 21.

8 Project of an International Declaration Concerning the Laws and Customs of War, Brussels, 27 August 1874 (dalej: deklaracja brukselska), https:/ / ihl-databases.icrc.org/ihl/ INTRO/135 [dostęp: 12.02.2020 r.].

9 Zob H. Schreiber, Konwencja o ochronie dóbr kulturalnych..., s. 22. 
uznawały, że strony wojujące powinny zastosować wszelkie niezbędne środki, ażeby obiekty takie jak „świątynie, gmachy, służące celom nauki, sztuki i dobroczynności, pomniki historyczne, szpitale oraz miejsca, gdzie zgromadzeni są chorzy i ranni" zostały oszczędzone ${ }^{10}$. Jednakże obiekty te miały być oszczędzone „w miarę możliwości”, co w rzeczywistości znacznie osłabiało przyznaną im ochronę. Dużą wadą ówczesnego systemu ochrony była możliwość uchylenia się od konieczności stosowania konwencji na podstawie klauzuli powszechności. Ponadto postanowienia konwencji miały zastosowanie jedynie w sytuacji wojny wypowiedzianej i za taką przez strony konfliktu uznaną.

Społeczność międzynarodowa ciągle poszukiwała sposobu zapewnienia pełnej ochrony dobrom kultury, czego najlepszym przykładem jest Pakt Roericha ${ }^{11}$ - choć miał on znaczenie jedynie regionalne, będąc umową półotwartą, dostępną tylko dla członków Unii Panamerykańskiej ${ }^{12}$, stał się pierwszym aktem poświęconym w całości obiektom kultury. Potrzeba stworzenia międzynarodowego systemu ochrony dóbr kultury została dostrzeżona przez Zgromadzenie Ligii Narodów, jednak wybuch II wojny światowej uniemożliwił komitetowi ekspertów dalsze prace nad dokumentem prawa międzynarodowego zapewniającym dostateczną ochronę dobrom kultury. Zniszczenia wojenne, na niespotykaną dotąd skalę, dobitnie uświadomiły społeczności międzynarodowej, że szczątkowa regulacja konwencji haskich dotycząca dóbr kultury jest niewystarczająca wobec zagrożeń związanych z nowymi możliwościami prowadzenia wojny. Odpowiedzią na owe zagrożenia miała stać się Konwencja haska o ochronie dóbr kulturalnych w razie konfliktu zbrojnego, przyjęta dnia 14 maja 1954 r. na Konferencji Generalnej Organizacji Narodów Zjednoczonych do Spraw Oświaty, Nauki i Kultury (United Nations Educational, Scientific and Cultural Organization, UNESCO) w Hadze ${ }^{13}$. Konwencja ta nie tylko po raz pierwszy definiuje pojęcie „dóbr kultury”, czyniąc je

10 Art. 27 Konwencji dotyczącej praw i zwyczajów wojny lądowej, Haga, 18 października 1907 r., Dz. U. z 1927 r. Nr 21, poz. 161 (dalej: IV konwencja haska z 1907 r.).

11 Treaty on the Protection of Artistic and Scientific Institutions and Historic Monuments (Roerich Pact), Washington, 15 April 1935, https://ihl-databases.icrc.org/ihl/ INTRO/325?OpenDocument [dostęp: 12.02.2020 r.].

12 Zob. H. Nieć, Ojczyzna dzieła sztuki. Międzynarodowa ochrona integralności narodowej spuścizny kulturalnej, Kraków 1980, s. 54.

13 Konwencja o ochronie dóbr kulturalnych w razie konfliktu zbrojnego wraz z Regulaminem wykonawczym do tej Konwencji oraz Protokół o ochronie dóbr kulturalnych 
przedmiotem ochrony prawa międzynarodowego, ale także wprowadza pojęcie "dziedzictwa kultury", do którego odwołano się w preambule konwencji.

Przyjęta w konwencji definicja „dóbr kulturalnych” jest wynikiem ożywionej dyskusji, jaka miała miejsce podczas prac przygotowawczych. W kwestii sformułowania definicji zwyciężyły względy praktyczne, na które zwracała uwagę delegacja amerykańska, podkreślając, że przykładowe wyliczenie jest szczególnie przydatne dla oficerów identyfikujących obiekty chronione podczas wojny ${ }^{14}$. Tym samym dobra kultury w Konwencji haskiej z 1954 r. to m.in.: dobra ruchome lub nieruchome, posiadające wielką wagę dla dziedzictwa kulturalnego narodu, będące zabytkami architektury, sztuki lub historii; stanowiskami archeologicznymi; zespołami budowlanymi; dziełami sztuki, rękopisami, książkami i innymi przedmiotami o znaczeniu artystycznym, a także gmachy, których przeznaczeniem jest przechowywanie lub wystawianie dóbr kulturalnych ruchomych ${ }^{15}$.

Konwencja haska nakłada na państwa-strony szereg obowiązków, takich jak obowiązek opieki, czyli podjęcie działań przygotowawczych (np. poprzez oznaczanie dóbr kultury lub sporządzanie inwentarzy) już w czasach pokoju oraz poszanowania, który dotyczy zarówno stanu pokoju, jak i wojny i jest nie tylko obowiązkiem państwa-strony, na której terytorium znajduje się dany obiekt, ale także strony przeciwnej, podejmującej działania zbrojne. Blisko 40-letnia praktyka stosowania postanowień konwencyjnych w konfliktach zbrojnych, wydarzenia wojny w Zatoce Perskiej oraz toczącej się wojny na Półwyspie Bałkańskim ujawniły niedoskonałości stworzonego systemu i zaowocowała przekonaniem o konieczności rewizji postanowień konwencyjnych ${ }^{16}$. Stąd też w 1999 r. przyjęto Drugi Protokół dodatkowy do Konwencji haskiej z 1954 r. Znacznym novum protokołu względem konwencji jest zdefiniowanie w art. 15 pięciu przestępstw, których sprawcy mogą podlegać międzynarodowej odpowiedzialności karnej. Do przestępstw tych należy: czynienie celem ataku dóbr kultury

w razie konfliktu zbrojnego, podpisane w Hadze dnia 14 maja 1954 r., Dz. U. z 1957 r. Nr 46, poz. 212, zał. (dalej: Konwencja haska z 1954 r.).

14 Zob. A. Przyborowska-Klimczak, Rozwój ochrony dziedzictwa kulturalnego w prawie międzynarodowym na przełomie XX i XXI wieku, Lublin 2011, s. 21.

15 Art. 1 Konwencji haskiej z 1954 r.

16 Według ekspertów chorwackich w wyniku działań wojennych spowodowanych serbsko-czarnogórską agresją zostało uszkodzonych bądź zniszczonych 1313 obiektów sakralnych, zob. H. Schreiber, Konwencja o ochronie dóbr kulturalnych..., s. 124. 
objętych ochroną wzmocnioną, wykorzystywanie dóbr kultury objętych taką ochroną do wsparcia działań militarnych, powodowanie rozległych zniszczeń, zawłaszczanie oraz czynienie celem ataku dóbr kultury objętych ochroną na mocy Konwencji haskiej z 1954 r. lub Drugiego Protokołu, a także kradzież, rabunek, przywłaszczenie oraz akty wandalizmu skierowane przeciwko dobrom kultury objętym ochroną na mocy konwencji. Na mocy art. 16 ust. 1 lit (c) państwa-strony są zobowiązane do wykonywania jurysdykcji uniwersalnej w stosunku do sprawców pierwszych trzech z pięciu poważnych naruszeń zobowiązań haskich. Ponadto Drugi Protokół zawiera szereg szczegółowych regulacji dotyczących ścigania sprawców takich przestępstw, ich ekstradycji, wzajemnej pomocy prawnej oraz penalizacji innych czynów skierowanych przeciwko dobrom kultury chronionym w ramach systemu haskiego ${ }^{17}$. Co istotne, Drugi Protokół ma zastosowanie zarówno w konfliktach międzynarodowych, jak i w konfliktach nieposiadających takiego charakteru ${ }^{18}$. Choć jak podkreśla J.M. Henckaerts, teoretycznie zastosowanie Drugiego Protokołu do konfliktów nie międzynarodowych ma fundamentalne znaczenie dla ochrony dóbr kulturalnych, jako że obecnie większość konfliktów ma właśnie taki charakter $^{19}$, praktycznie jednak ochrona ta okazała się niewystarczająca ${ }^{20}$, czego najdobitniejszym przykładem jest ogrom zniszczeń podczas trwających konfliktów w Iraku i Syrii, czy też zniszczenie posągów Buddy w Bamjan w Afganistanie, pochodzących z IV w. Społeczność międzynarodowa była oburzona, kiedy to $\mathrm{w}$ marcu 2001 r. talibańscy przywódcy podjęli decyzję o wysadzeniu posągów argumentując ją zakazem przedstawień ludzkich czy zwierzęcych w Islamie ${ }^{21}$. Bezpośrednią reakcją na zniszczenie posągów było przyjęcie przez UNESCO Deklaracji dotyczącej celowego

17 Zob. K. Wierczyńska, A. Jakubowski, Zbrodnie przeciwko dziedzictwu kulturowemu przed Międzynarodowym Trybunałem Karnym - analiza krytyczna, "Studia Prawnicze” 2016, z. 1, s. 46.

18 Konwencja haska z 1954 r. również znajduje zastosowanie w przypadku konfliktów o charakterze nie międzynarodowym, wyznaczając minimum, jakim jest obowiązek poszanowania dóbr kulturalnych w czasie owych konfliktów (art. 16).

19 Drugi Protokół do Konwencji o ochronie dóbr kulturalnych w razie konfliktu zbrojnego, podpisanej w Hadze dnia 14 maja 1954 r., sporządzony w Hadze 26 marca 1999 r., Dz. U. z 2012 r. poz. 248 (dalej: Drugi Protokół).

20 Zob. J.M. Henckaerts, New Rules for the Protection of Cultural Property in Armed Conflict, "International Review of the Red Cross” 1999, nr 835, s. 618.

${ }^{21}$ Zob. D. Fincham, Intentional Destruction and Spoliation of Cultural Heritage Under International Criminal Law, „U.C. Davis Journal Of International Law \& Policy” 2017, 
niszczenia dziedzictwa kulturowego ${ }^{22}$, która w punkcie VII stwierdza, że państwa powinny powziąć wszelkie możliwie środki do ustanowienia jurysdykcji uniwersalnej i wprowadzenia skutecznych sankcji karnych wobec bezpośrednich sprawców lub wydających rozkazy celowego zniszczenia dziedzictwa kultury o największym znaczeniu dla ludzkości, bez względu, czy są one wpisane na listę ustanowioną przez UNESCO lub jakąkolwiek inną organizację międzynarodową ${ }^{23}$. Dobra kultury stają się celem ataku różnych grup ekstremistycznych przede wszystkim ze względu na ich znaczenie dla poszczególnych grup religijnych czy społecznych. Znaczenie to odzwierciedlone zostało w pojęciu „dziedzictwa kulturalnego". Pojęcie dziedzictwa, podobnie zresztą jak pojęcie kultury, jest jednym z tych pojęć, którego definicja sprawia trudności, szczególnie jeśli chodzi o możliwości normatywne. Niewątpliwie dziedzictwo jest pojęciem szerszym od dobra kultury ${ }^{24}$. W sferze prawa międzynarodowego pojęcie dziedzictwa pojawia się po raz pierwszy w preambule Konwencji haskiej z 1954 r.:

[Wysokie Umawiające się Strony - K.P.] przeświadczone, że szkody wyrządzone dobrom kulturalnym, do jakiegokolwiek należałyby one narodu, stanowią uszczerbek w dziedzictwie kulturalnym całej ludzkości, gdyż każdy naród ma swój udział w kształtowaniu kultury światowej; zważywszy, że zachowanie dziedzictwa kulturalnego posiada wielkie znaczenie dla wszystkich narodów świata i że jest rzeczą doniosłą zapewnić temu dziedzictwu ochronę międzynarodową ${ }^{25}$.

s. 149-192, https://jilp.law.ucdavis.edu/issues/volume-23-2/jilp-23-2-Fincham.pdf [dostęp: $22.05 .2018 \mathrm{r}$.].

22 UNESCO Declaration Concerning the Intentional Destruction of Cultural Heritage, 17 October 2003 [Records of General Conference, 32 ${ }^{\text {nd }}$ Session, Paris 2003], http:/ / portal. unesco.org/en/ev.php-URL_ID=17718\&URL_DO=DO_TOPIC\&URL_SECTION=201. html [dostęp: 3.02.2020 r.].

${ }_{23}$ Do tejże Deklaracji odniósł się również Parlament Europejski w Rezolucji z dnia 30 kwietnia 2015 r. w sprawie niszczenia zabytków kultury przez ISIS/Daisz, w której potępił działania grup ekstremistycznych związane z niszczeniem dziedzictwa kulturalnego, zob. Rezolucja Parlamentu Europejskiego z dnia 30 kwietnia 2015 r. w sprawie niszczenia zabytków kultury przez ISIS/Daisz (2015/2649(RSP), Dz. Urz. UE C 346 z 21.09.2016, s. 55-59.

${ }^{24}$ Zob. K. Zeidler (red.), Leksykon prawa ochrony zabytków. 100 podstawowych pojęć, Warszawa 2010, s. 186-187.

25 Preambuła Konwencji haskiej z 1954 r. 
Celem stworzonego systemu ochrony dóbr kultury nie jest zatem ochrona pojedynczych, pozornie niezwiązanych ze sobą obiektów, lecz ochrona pewnej całości. Całością tą jest właśnie dziedzictwo. Choć odniesienie zawarte $\mathrm{w}$ preambule jest niejako intuicyjne, to podkreśla ono ponadczasowe znaczenie chronionych obiektów oraz cel, jakim jest zachowanie ich dla przyszłych pokoleń. Normatywne określenie dziedzictwa przyniosła dopiero Konwencja w sprawie ochrony światowego dziedzictwa kulturalnego i naturalnego z 1972 r. ${ }^{26}$ Definicja przyjęta w konwencji zbudowana jest na podstawie enumeratywnego wyliczenia obiektów, które mogą zostać zaklasyfikowane jako dziedzictwo. Do obiektów tych należą m.in.: zabytki, czyli dzieła architektury, rzeźby i malarstwa; budowle o charakterze archeologicznym; miejsca zabytkowe oraz stanowiska archeologiczne. Obiekty te powinny cechować się „wyjątkową powszechną wartością" z punktu widzenia historycznego, estetycznego, etnologicznego lub antropologicznego, aby móc zostać wpisane na Listę Światowego Dziedzictwa stworzoną na mocy tej konwencji. Definicja dziedzictwa przyjęta w 1972 r. różni się znacząco od definicji przyjmowanych przez inne dziedziny nauki - przede wszystkim antropologii. W najprostszy sposób antropologiczną definicję dziedzictwa można określić jako roszczenie danej grupy ludzi względem jakiejś konkretnej części ich przeszłości ${ }^{27}$. Jest to definicja niezwykle szeroka - zrozumiałe zatem, że nie mogła stać się ona definicją normatywną. Jednak pominięcie czynnika ludzkiego w definiowaniu dziedzictwa pozbawia definicję normatywną prawdziwego znaczenia, jakie dziedzictwo odgrywa w życiu ludzkim oraz funkcji, jaką dziedzictwo to pełni, wpływając na tożsamość oraz ludzką godność. Zarówno definicja "dóbr kultury” oraz definicja "dziedzictwa kulturowego" w prawie międzynarodowym są poniekąd wynikiem zachodniej koncepcji kultury, która utożsamiana była przede wszystkim z kulturą wysoką oraz jej materialnymi przedstawieniami, takimi jak dzieła malarstwa czy architektury. Takie też rozumienie kultury przyświecało twórcom art. 15 Międzynarodowego Paktu Praw

26 Konwencja w sprawie ochrony światowego dziedzictwa kulturalnego i naturalnego, przyjęta w Paryżu dnia 16 listopada 1972 r. przez Konferencję Generalną Organizacji Narodów Zjednoczonych dla Wychowania, Nauki i Kultury na jej siedemnastej sesji, Dz. U. z 1976 r. Nr 32, poz. 190.

27 Szerzej zob. I. Hodder, Cultural Heritage Rights: From Ownership and Descent to Justice and Well-being, "Anthropological Quarterly" 2010, t. 83, nr 4, s. 862-864. 
Gospodarczych, Społecznych i Kulturalnych z 1966 r. ${ }^{28}$ Ujęte w nim prawo do udziału w życiu kulturalnym oznaczało przede wszystkim możliwości uczestniczenia w kulturze wysokiej i ograniczało się do instytucji takich jak muzea czy galerie sztuki ${ }^{29}$.

Wraz z rozwojem badań nad dziedzictwem, prowadzonych m.in. pod egidą UNESCO oraz przyjęciem szeregu dokumentów typu soft-law - jak choćby Zalecenie UNESCO dotyczące udziału ogółu ludzkości w życiu kulturalnym ${ }^{30}$ czy też Powszechna deklaracja o różnorodności kulturowe $^{31}$ - nastąpiła istotna zmiana $\mathrm{w}$ postrzeganiu dziedzictwa $\mathrm{w}$ prawie międzynarodowym. Nastąpiło swego rodzaju przejście od ochrony wąsko pojmowanego dobra kultury do kompleksowego systemu ochrony dziedzictwa. Świadczy o tym zarówno przyjęcie w 2003 r. przez UNESCO Konwencji w sprawie ochrony niematerialnego dziedzictwa kulturowego $^{32}$, jak i Komentarza do art. 15 Międzynarodowego Paktu Praw Gospodarczych, Społecznych i Kulturalnych ${ }^{33}$. Konwencja z 2003 r. definiuje dziedzictwo niematerialne jako:

praktyki, wyobrażenia, przekazy, wiedzę i umiejętności - jak również związane z nimi instrumenty, przedmioty, artefakty i przestrzeń kulturową - które

28 Międzynarodowy Pakt Praw Gospodarczych, Społecznych i Kulturalnych otwarty do podpisu w Nowym Jorku dnia 19 grudnia 1966 r., Dz. U. z 1977 r. Nr 38, poz. 169.

29 United Nations Economic and Social Council, Committee on Economic, Social and Cultural Rights, Cultural Life in the Context of Human Rights. Background paper submitted by Ms. Yvonne Donders, 9 May 2008, E/C.12/40/13, s. 3, https://www.scribd.com/document/120158385/ Donders-Cultural-Life-in-the-Context-of-Human-Rights [dostęp: 3.02 .2020 r.]; A. Vrdoljak, The Cultural Dimension of Human Rights, Oxford 2013.

30 United Nations Educational, Scientific and Cultural Organization, Recommendation on Participation by the People at Large in Cultural Life and Their Contribution to It, 26 November 1976, http:/ / portal.unesco.org/en/ev.php-URL_ID=13097\&URL_DO=DO_ TOPIC\&URL_SECTION=201.html [dostęp: 3.02.2020 r.].

31 UNESCO Universal Declaration on Cultural Diversity, 2 November 2001, http:/ / portal.unesco.org/en/ev.php-URL_ID=13179\&URL_DO=DO_TOPIC\&URL_SECTION=201.html [dostęp: 3.02.2020 r.].

32 Konwencja UNESCO w sprawie ochrony niematerialnego dziedzictwa kulturowego, sporządzona w Paryżu dnia 17 października 2003 r., Dz. U. z 2011 r. Nr 172, poz. 1018 (dalej: Konwencja z 2003 r.).

33 United Nations Economic and Social Counsil. Committee on Economic, Social and Cultural Rights, General Comment No. 21. Right of Everyone to Take Part in Cultural Life (art. 15, par. 1(a) of the International Covenant on Economic, Social and Cultural Rights), 21 December 2009, E/C.12/GC/21 (dalej: Komentarz nr 21 do art. 15 paktu), https:// www.refworld.org/docid/4ed35bae2.html [dostęp: 3.02.2020 r.]. 
wspólnoty, grupy i, w niektórych przypadkach, jednostki uznają za część własnego dziedzictwa kulturowego. To niematerialne dziedzictwo kulturowe, przekazywane z pokolenia na pokolenie, jest stale odtwarzane przez wspólnoty i grupy w relacji z ich otoczeniem, oddziaływaniem przyrody i ich historią oraz zapewnia im poczucie tożsamości i ciągłości, przyczyniając się w ten sposób do wzrostu poszanowania dla różnorodności kulturowej oraz ludzkiej kreatywności ${ }^{34}$.

Definicja ta $w$ jasny sposób nawiązuje do definicji antropologicznych, jako że przyznaje grupom i społecznościom prawo do decydowania o tym, co jest ich dziedzictwem. Co więcej, dalsza część definicji podkreśla ten element dziedzictwa, który wiąże się z chęcią przekazywania go z pokolenia na pokolenie oraz podkreśla jego dynamiczny aspekt. Zgodnie z Komentarzem nr 21 do art. 15 paktu kultura jest rozumiana nie jako seria pojedynczych przejawów, ale jako interaktywny proces, w którym jednostki i społeczności, zachowując swoją odrębność, dają wyraz kulturze ludzkości. Na mocy art. 15 państwa-strony są zobowiązane do poszanowania i ochrony dziedzictwa kulturowego we wszystkich jego formach, zarówno w czasach konfliktu zbrojnego, jak i w czasach pokoju. Dziedzictwo kulturowe musi być zachowane, rozwijane i przekazywane z pokolenia na pokolenie jako dowód ludzkich przeżyć i osiągnięć, zaś każda społeczność ma prawo dostępu i możliwości korzystania z własnego dziedzictwa ${ }^{35}$. Rok 2009 przyniósł nie tylko przyjęcie wspomnianego Komentarza nr 21, ale także powołanie przez Radę Praw Człowieka stanowiska niezależnego eksperta do spraw praw kulturalnych, któremu w 2012 r. przyznano status Specjalnego Sprawozdawcy do spraw praw kulturalnych. W raporcie z 2011 r., F. Shaheed, uznała, że:

podejście do dziedzictwa kulturowego oparte na prawach człowieka jest niezbędne w celu zachowania tego dziedzictwa. Poza obowiązkiem ochrony dziedzictwa samego w sobie, zobowiązuje ono także do wzięcia pod uwagę

34 Art 2 Konwencji z 2003 r.

35 United Nations Economic and Social Counsil. Committee on Economic, Social and Cultural Rights, General Comment No. 21. Right of Everyone to Take Part in Cultural Life (art. 15, par. 1(a) of the International Covenant on Economic, Social and Cultural Rights), 21 December 2009, E/C.12/GC/21, par. 49-50, https://www.refworld.org/ docid/4ed35bae2.html [dostęp: 3.02.2020 r.]. 
prawa jednostek i społeczności w związku z danym obiektem, co ma wpływ na ich tożsamość, godność, poczucie ciągłości i przynależności ${ }^{36}$.

Zmiana w postrzeganiu dziedzictwa oznacza zatem przyjęcie, że jego ochrona wykracza poza ochronę miejsc, zabytków konkretnych przedmiotów czy artefaktów. To, co podlega ochronie jest przede wszystkim elementem niematerialnym. Element ten może oznaczać zarówno wszelkie praktyki i rytuały, lecz także wartości, jak chociażby chęć przekazania go kolejnym pokoleniom. Można zatem uznać, że dziedzictwo kulturowe w prawie międzynarodowym jest definiowane jako warte ochrony ze względu na jego znaczenie - z jednej strony dla kultury światowej i całej społeczności międzynarodowej, z drugiej zaś dla mniejszych społeczności, bezpośrednio związanych $\mathrm{z}$ danym dziedzictwem, które stanowi obiekt ich codziennych rytuałów, będących częścią ich tożsamości kulturowej. Podejście to zostało odzwierciedlone zarówno w argumentacji prokurator MTK, jak i do pewnego stopnia w treści wyroku w sprawie Ahmada Al Faqi Al Mahdiego, oskarżonego o popełnienie zbrodni wojennej, polegającej na celowym kierowaniu ataków na budynki przeznaczone na cele religijne, edukacyjne, artystyczne, naukowe lub pomniki historyczne.

\section{Sprawa Al Mahdiego przed Międzynarodowym Trybunałem Karnym}

\subsection{Stan faktyczny}

Od momentu ogłoszenia niepodległości w 1960 r. Mali stało się areną konfliktów wewnętrznych. W dużej mierze jest to spowodowane walką plemienia Tauregów - będącego nomadycznym ludem berberyjskim zamieszkującym saharyjski interior Północnej i Zachodniej Afryki - o utworzenie własnego państwa, Azawadu, którego tereny obejmują północną część terytorium Mali ${ }^{37}$. W styczniu 2012 r. tuarescy rebelianci, zjedno-

36 United Nations Human Rights Council, Report of the Independent Expert in the Field of Cultural Rights, 21 March 2011, A/HRC/17/38, par. 2, https://www.refworld.org/ docid/50f01fb12.html [dostęp: 12.02.2020 r.].

37 Szerzej zob. K. Kubiak, Konflikt w Mali. Rebelia Tuaregów, islamiści i międzynarodowa interwencja, „Przegląd Politologiczny” 2014, nr 1, s. 351-368. 
czeni jako Narodowy Ruch Wyzwolenia Azawadu (MNLA), rozpoczęli ofensywę, w wyniku której władze centralne utraciły kontrolę nad kilkoma większymi miastami, a rebelianci zdobyli kontrolę nad większością terenu Azawadu. Wkrótce jednak, islamistyczne ugrupowania ekstremistyczne, które do tej pory wspierały MNLA w walce z rządem, rozpoczęły własne działania zbrojne, mające na celu przejęcie kontroli w północnej części Mali. W kwietniu 2012 r., wykorzystując wycofanie się wojsk rządowych, jedno z głównych ugrupowań islamistycznych, Ansar Dine, mające powiązania z Al Ka'idą Islamskiego Magrebu (AQIM), przejęło kontrolę w Timbuktu. Głównym celem Ansar Dine było wprowadzenie porządku opartego na radykalnej interpretacji szariatu. W tym celu powołano islamski trybunał, policję, media comission oraz brygadę moralności zwaną Hesbah. W kwietniu 2012 r. przywódcą Hesbah, ze względu na swoje wykształcenie oraz dogłębną znajomość Koranu został, cieszący się dużą estymą wśród przywódców Ansar Dine, Ahmad Al Faqi Al Mahdi ${ }^{38}$. Głównym zadaniem Hesbah była kontrola moralności mieszkańców Timbuktu poprzez przeciwdziałanie, tłumienie oraz karanie wszystkiego, co przez okupantów rozumiane było jako moralny występek ${ }^{39}$. Szczególny sprzeciw budziły tradycyjne rytuały i ceremonie mieszkańców Timbuktu związane z oddawaniem czci świętym, którym poświęcono liczne mauzolea. Mauzolea te, będąc przykładem typowej dla tego regionu architektury, były dowodem świetności Timbuktu, jako intelektualnej i duchowej stolicy, która ze względu na swoje położenie geograficzne stała się centrum propagowania Islamu w XV i XVI w. ${ }^{40}$ Wyjątkowa powszechna wartość mauzoleów doceniona została przez społeczność międzynarodową, kiedy to w 1988 r., wraz z trzema meczetami, zostały one wpisane na Listę Światowego Dziedzictwa UNESCO. Mauzolea te reprezentują znaczenie jakie przypisuje się muzułmańskim świętym - uważane są za ich „ostatni dom”, a samo Timbuktu zwane jest miastem 333 Świętych ${ }^{41}$.

38 Zob. International Criminal Court, Prosecutor v. Ahmad Al Faqi Al Mahdi, ICC-01/12-01/15, Judgement and Sentence (public), 27 September 2016, par. 31, https:/ / www.icc-cpi.int/CourtRecords/CR2016_07244.PDF [dostęp: 3.02.2020 r.].

39 Zob. tamże, par. 33.

40 Zob. P. Gerstenblith, The Destruction of Cultural Heritage: A Crime Against Property or a Crime Against People?, "The John Marshall Review of Intellectual Property Law" 2016, s. 356.

${ }^{41}$ Zob. International Criminal Court, Prosecutor v. Ahmad al Faqi al Mahdi, ICC-01/12-01/15 [public redacted version of "Prosecution's submissions on sentencing” 
Jednakże, dla przywódców Ansar Dine mauzolea oraz rytuały miejscowej ludności z nimi związane były nie do przyjęcia - uważali oni wszelkie konstrukcje wzniesione ponad grobami oraz oddawanie czci pochowanym w nich zmarłym za zakazane ${ }^{42}$. Początkowo rolą Al Mahdiego miała być obserwacja cmentarzy, a także spotkania z lokalnymi przywódcami religijnymi oraz podniesienie świadomości mieszkańców co do zakazanych praktyk. Kiedy działania te nie przyniosły spodziewanych efektów, głównodowodzący Ansar Dine podjęli decyzję o zniszczeniu mauzoleów. Mimo wstępnych zastrzeżeń co do planowanej akcji, która jak twierdził zaprzepaści szansę na przyjazne relacje między okupantami a mieszkańcami Timbuktu, oskarżony Al Mahdi, będąc przywódcą Hesbah, zgodził się jednak przygotować i przeprowadzić akcję. Atak, podczas którego zniszczono dziesięć mauzoleów, z których dziewięć wpisanych było na Listę Światowego Dziedzictwa, miał miejsce w dniach od 30 czerwca 2012 r. do 11 lipca 2012 r., a jego rozłożenie w czasie oraz szerokie rozpropagowanie $\mathrm{w}$ lokalnych mediach dodatkowo przyczyniło się do cierpienia miejscowej ludności.

\subsection{Zarzuty sformułowane przez prokurator}

Już dnia 1 lipca 2012 r. prokurator F. Bensouda wystosowała publiczne oświadczenie, w którym podkreślała, że celowe niszczenie świątyń położonych w Timbuktu stanowi zbrodnię wojenną w rozumieniu Statutu Rzymskiego ${ }^{43}$. W efekcie akcji nadzorowanej przez Al Mahdiego zniszczeniu uległy: Mauzoleum Sidi Mahamoud Ben Omar Mohamed Aquit, Mauzoleum Sheikh Mohamed Mahmoud Al Arawani, Mauzoleum Sheikh Sidi El Mokhtar Ben Sidi Mouhammad Al Kabir Al Kounti, Mauzoleum Alpha Moya, Mauzoleum Sheikh Mouhamad El Mikki, Mauzoleum Sheikh Abdoul Kassim Attouaty, Mauzoleum Sheikh Sidi Ahmed Ben Amar Arragadi, dwa mauzolea przylegające do Meczetu Djingareyber," szczególnie odwiedzane w poniedziałki i piątki oraz z okazji

in the Al Mahdi case], 22 July 2016, par. 27, https://www.icc-cpi.int/CourtRecords/ CR2016_05672.PDF [dostęp: 3.02.2020 r.].

42 Zob. International Criminal Court, Prosecutor v. Ahmad Al Faqi Al Mahdi, ICC01/12-01/15, Judgement and Sentence (public), 27 September 2016, par. 36.

43 Zob. S. Stryjkowska, Problematyka ochrony dziedzictwa kulturowego w działalności międzynarodowych trybunatów karnych, „Przegląd Prawniczy Uniwersytetu im. Adama Mickiewicza" 2016, t. 6, s. 218. 
specjalnych uroczystości, a także zabytkowe drzwi Meczetu Sidi Yahia, których otwarcie według tradycji miało doprowadzić do sądu ostatecznego. Centralnym argumentem zarzutów sformułowanych przez prokurator, wokół którego niejako stworzony został cały akt oskarżenia, jest nie tyle zniszczenie świątyń w ich materialnym wyrazie, lecz przede wszystkim atak na tożsamość kulturową ludności Timbuktu. Jak wskazała prokurator, powołując się na zeznania świadków, dla lokalnej społeczności mauzolea były niezwykle istotne w codziennym życiu. Były nie tylko miejscem modlitwy, pielgrzymek, czytania wersetów Koranu i duchowego wyciszenia, lecz także miejscem celebrowania uroczystości takich jak rytualne obrzezanie czy Maouloud, będące upamiętnieniem urodzin Proroka Mahometa ${ }^{44}$. Zniszczone budynki oraz związane z nimi tradycje i rytuały były także elementem spajającym całą społeczność - o ich zachowanie dbała wspólnie okoliczna ludność, która z pokolenia na pokolenie przekazywała sobie szacunek i wiedzę na ich temat. Przedstawiciel cechu murarzy, posiadający specjalistyczną wiedzę o konserwacji ścian mauzoleów za pomocą tynkowania gliną, został nazwany przez Malijskiego Ministra Kultury Żywym Skarbem Ludzkim (ang. Living Human Treasure) ${ }^{45}$. Mauzolea były zatem nie tylko symbolem miasta, ale przede wszystkim materialnym przejawem kulturowej tożsamości samych mieszkańców Timbuktu, a wedle słów jednego ze świadków przytoczonych w akcie oskarżenia „codzienne modlitwy w mauzoleach miały ogromne znaczenie dla równowagi, moralności i wiary, pozwalając mieszkańcom wyrażać swoją wizję świata" ${ }^{46}$. Stąd też, zdaniem prokurator, szkody wyrządzone przez tę zbrodnię są $\mathrm{w}$ dużej mierze nieodwracalne - nie tylko ze względu na utracenie przez miasto oraz zabytki cech autentyczności, ale przede wszystkim ze względu na utratę poczucia wartości oraz

${ }_{44}$ Zob. International Criminal Court, Prosecutor v. Ahmad al Faqi al Mahdi, ICC01/12-01/15 [public redacted version of "Prosecution's submissions on sentencing” in the Al Mahdi case], 22 July 2016, par. 25.

45 Zob. tamże, par. 26. Living Human Treasure jest jednym z programów UNESCO, związanym z ochroną dziedzictwa niematerialnego, zob. A. Przyborowska-Klimczak, Międzynarodowa Ochrona Niematerialnego Dziedzictwa Kulturalnego, „Problemy Współczesnego Prawa Międzynarodowego, Europejskiego i Porównawczego" 2005, t. 3, s. 5-21.

46 International Criminal Court, Prosecutor v. Ahmad al Faqi al Mahdi, ICC-01/12-01/15 [public redacted version of "Prosecution's submissions on sentencing" in the Al Mahdi case], 22 July 2016, par. 25. 
tożsamości bezpośrednio poszkodowanych, którą w przeciwieństwie do mauzoleów, niełatwo będzie odbudować ${ }^{47}$.

Prokurator w akcie oskarżenia odniosła się również do długoletniej historii zakazu niszczenia dóbr kulturalnych w prawie międzynarodowym, wskazując, iż obecnie zakaz ten jest ugruntowany i niebudzący zastrzeżeń, co z kolei podkreśla poważny charakter zbrodni polegającej na przeprowadzaniu ataków na dobra kultury - szczególnie kiedy atakowane zabytki pozbawione są wartości wojskowej. Dowodem na znaczenie owego zakazu jest również reakcja społeczności międzynarodowej - zniszczenie mauzoleów w Timbuktu potępiła m.in. Rada Bezpieczeństwa ONZ, Unia Afrykańska, Wspólnota Gospodarcza Państw Afryki Zachodniej, UNESCO oraz poszczególne państwa ${ }^{48}$. Prokurator wielokrotnie podkreślała, że udział Al Mahdiego w zniszczeniu mauzoleów miał krytyczne znaczenie dla powodzenia zaplanowanej akcji - nie tylko zidentyfikował on obiekty, które miały ulec zniszczeniu i zwrócił uwagę przywódców Ansar Dine na rytuały okolicznej ludności związane z tymi miejscami, lecz także poinformował media o nadchodzącym ataku, określił kolejność oraz nadzorował niszczenie obiektów, dostarczając niezbędnych materiałów, a także moralnego wsparcia pozostałym sprawcom oraz sam brał udział w zniszczeniu mauzoleów, m.in. poprzez wyjmowanie cegieł ze ścian budynków ${ }^{49}$. Zważywszy na chęć współpracy oskarżonego, dostarczenie przez niego wielu informacji istotnych dla sprawy oraz przyjęcie odpowiedzialności i przyznanie się do winy już na wstępnym etapie postępowania, prokurator wniosła o karę w wymiarze od 9 do 11 lat pozbawienia wolności.

\subsection{Przebieg postępowania}

We wrześniu 2015 r. na podstawie nakazu aresztowania wydanego przez Izbę Przygotowawczą MTK, Al Mahdi został aresztowany i przewieziony do Hagi. Dnia 17 grudnia 2015 r. Biuro Prokuratora MTK wniosło zarzuty w związku z naruszeniem jednego tylko artykułu Statutu

47 Zob. tamże, par. 28.

48 Zob. ICC, Prosecutor v. Ahmad al Faqi al Mahdi, ICC-01/12-01/15 [public redacted version of „Prosecution's submissions on sentencing” in the Al Mahdi case], 22 July 2016, par. 29.

49 Zob. tamże, par. 41-43. 
Rzymskiego - art. 8 ust. 2 lit (e) (iv), dotyczącego zamierzonego kierowania ataków na budynki przeznaczone m.in. na cele religijne oraz pomniki historyczne. Dnia 24 marca 2016 r. Izba Przygotowawcza MTK potwierdziła zarzut zbrodni wojennej przeciwko Ahmadowi al-Faqi al-Mahdiemu, a dnia 24 maja 2016 r. odbyło się pierwsze posiedzenie Izby Orzekającej. Podczas procesu trwającego w dniach od 22 do 24 sierpnia 2016 r. oskarżony potwierdził początkowy zamiar przyznania się do winy oraz wyraził skruchę. Był to nie tylko najkrótszy proces toczący się przed MTK, lecz także pierwszy, kiedy zastosowano art. 65 Statutu Rzymskiego. Artykuł ten, umożliwiający oskarżonemu przyznanie się do winy, wzbudził szereg kontrowersji podczas prac nad Statutem Rzymskim, przede wszystkim ze względu na konieczność pogodzenia dwóch kultur prawnych, tj. systemu prawa kontynentalnego oraz common law ${ }^{50}$. Zważywszy na doniosłą funkcję MTK, polegającą na sądzenia osób fizycznych oskarżanych o popełnienie najcięższych zbrodni, włączenie do statutu możliwości zawarcia ugody między Biurem Prokuratora a oskarżonymi wywołało sprzeciw wielu delegacji państw. Ostatecznie na podstawie dokumentu roboczego przygotowanego przez Argentynę w 1996 r._postanowiono wprowadzić do statutu możliwość przyznania się do winy oskarżonego, jednak z zastrzeżeniem, iż porozumienia pomiędzy prokuratorem a obroną, dotyczące zmiany zarzutów oskarżenia, przyznania się do winy lub wymiaru kary, nie będą dla MTK wiążące. Co więcej, zatwierdzenie przez Izbę Orzekającą przyznania się do winy oskarżonego nie oznacza automatycznego skazania i przejścia do fazy wymiaru kary, a Izba Orzekająca musi ustalić, czy przyznanie się do winy ma oparcie w okolicznościach faktycznych sprawy. W tym celu podczas procesu w sprawie Al Mahdiego przesłuchano samego oskarżonego, który dostarczył szczegółowych informacji, a także trzech świadków, w tym byłego dyrektora Centrum Światowego Dziedzictwa UNESCO, oraz wzięto pod uwagę szereg dokumentów i nagrań przedstawiających bezpośrednio zniszczenie dziedzictwa Timbuktu.

Dnia 27 września 2016 r. Izba Orzekająca MTK uznała Ahmada al-Faqi al-Mahdiego za winnego zarzucanego mu czynu, skazując go tym samym na dziewięć lat pozbawienia wolności. Na poczet kary zaliczono oskarżonemu czas, który spędził w areszcie, czyli od dnia 18 września 2015 r.

50 Zob. International Criminal Court, Prosecutor v. Ahmad Al Faqi Al Mahdi, ICC01/12-01/15, Judgement and Sentence (public), 27 September 2016, par. 21-27. 
Dnia 17 sierpnia 2017 r. odbyła się rozprawa dotycząca kwestii reparacji za wyrządzone szkody, podczas której zasądzono odszkodowanie oraz zadośćuczynienie o łącznej wysokości 2,7 mln euro za trzy kategorie szkód: zniszczenie budynków historycznych i religijnych, straty ekonomiczne związane ze zniszczeniem budynków oraz szkody moralne. Wypłata ma mieć formę kolektywną i służyć rekonstrukcji, renowacji i konserwacji obiektów zniszczonych w 2012 r. - ma być także odpowiedzią na szkody emocjonalne będące skutkiem zniszczenia dziedzictwa. Izba Orzekająca zasądziła również indywidualne odszkodowania dla osób, których środki utrzymania zależały wyłącznie od istnienia zniszczonych budynków oraz dla osób, których miejsca pochówku przodków zostały uszkodzone podczas ataku. Za wypłatę pieniędzy odpowiedzialny będzie specjalny fundusz - Trust Funds for Victims ${ }^{51}$.

\subsection{Treść wyroku i jego uzasadnienie}

Jako że był to pierwszy raz w historii, kiedy to oskarżonemu zarzucano popełnienie zbrodni ujętej w art. art. 8 ust. 2 lit (e) (iv) Statutu Rzymskiego, Izba Orzekająca przeanalizowała poszczególne elementy tej zbrodni. Aby dowieść zarzucaną zbrodnię, należy udowodnić, że:

1) sprawca kierował atakiem;

2) przedmiotem ataku był jeden lub kilka budynków przeznaczonych na cele religijne, edukacyjne, artystyczne, naukowe lub charytatywne, pomniki historyczne, szpitale oraz miejsca, gdzie gromadzeni są ranni i chorzy, pod warunkiem, że nie były one celami wojskowymi;

3) sprawca miał zamiar uczynić przedmiotem ataku wymienione budynki;

4) zarzucany czyn miał miejsce w związku z konfliktem zbrojnym o charakterze niemiędzynarodowym;

5) sprawca zdawał sobie sprawę z okoliczności faktycznych związanych $z$ danym konfliktem zbrojnym ${ }^{52}$.

Istnienie konfliktu zbrojnego o charakterze niemiędzynarodowym w owym czasie w Mali nie budzi wątpliwości. Na podstawie dowodów

51 Zob. Al Mahdi case: ICC Trial Chamber VIII issues reparations order, https:/ / www.icc-cpi.int/Pages/item.aspx?name=pr1329 [dostęp: 20.05.2019 r.].

52 Zob. International Criminal Court, Prosecutor v. Ahmad Al Faqi Al Mahdi, ICC01/12-01/15, Judgement and Sentence (public), 27 September 2016, par. 13. 
zgromadzonych w sprawie nie budzi również wątpliwości fakt znajomości przez oskarżonego okoliczności konfliktu oraz dominująca rola, jaką odegrał w zniszczeniu mauzoleów. Al Mahdi był nie tylko odpowiedzialny za planistyczną organizację ataku, określając jego czas oraz listę konkretnych mauzoleów - jego rola polegała również na wykorzystaniu funduszu Hesbah do zakupu niezbędnych narzędzi oraz jedzenia i napojów, sprawowaniu osobistego nadzoru nad każdym z ataków, a także dostarczaniu duchowego i ideologicznego wsparcia bezpośrednim sprawcom $^{53}$. Wątpliwości nie budzi również fakt, że oskarżony doskonale zdawał sobie sprawę, z roli i znaczenia, jakie odgrywały zniszczone mauzolea. Co więcej, to właśnie ich znaczenie stało się główną przyczyną ataku. Jak tłumaczył Al Mahdi w rozmowie z dziennikarzami, celem ataku było wykorzenienie zabobonów i herezji, które mogły doprowadzić do bałwochwalstwa ${ }^{54}$. Stąd też MTK uznał ponad wszelką wątpliwość, że przyznanie się do winy oskarżonego wraz z przeprowadzonymi dowodami, spełnia kryteria niezbędne do udowodnienia zarzucanego mu czynu. Aby określić wymiar kary Izba Orzekająca musiała rozważyć m.in. wagę zarzucanej zbrodni oraz indywidualne okoliczności dotyczące oskarżonego. Analizując wagę popełnionej zbrodni MTK wziął pod uwagę rozmiar wyrządzonej szkody, charakter bezprawnego zachowania oraz okoliczności czasu, miejsca i sposób jej popełnienia. Już na samym początku analizy ciężaru popełnionej zbrodni Izba Orzekająca dwukrotnie zastrzegła, iż zbrodnia ujęta w art. 8 ust. 2 lit (e) (iv) Statutu Rzymskiego, nawet jeśli z definicji jest ciężką zbrodnią, to jednak będąc wymierzona w mienie, charakteryzuje się zdecydowanie mniejszą powagą niż zbrodnie przeciwko osobom $^{55}$. Mimo to, zamierzone kierowanie ataku na obiekty wymienione w art. 8 ust. 2 lit (e) (iv) pozostaje zbrodnią wojenną i tym samym podlega jurysdykcji MTK. Swoje uzasadnienie Izba Orzekająca oparła na trzech argumentach dotyczących zniszczonego dziedzictwa: jego znaczeniu dla miejscowej ludności, jego znaczeniu dla społeczności międzynarodowej oraz motywacji towarzyszącej sprawcy ataku. W porównaniu z argumentacją zastosowaną przez prokurator F. Bensoudę Izba Orzekająca poświęciła zdecydowanie mniej miejsca na analizę związku lokalnej ludności ze zniszczonym dziedzictwem. Trybunał ograniczył się do wskazania, że

\footnotetext{
53 Zob. tamże, par. 84.

54 Zob. tamże, par. 38 (viii).

55 Zob. tamże, par. 72, 77.
} 
mauzolea istotnie miały duże znaczenie dla mieszkańców. Odzwierciedlając oddanie, jakie mieszkańcy Timbuktu odczuwają dla swojej religii, mauzolea odgrywały psychologiczną czy wręcz ochronną rolę w ich życiu. Trybunał przyznał, iż fakt, że budynki będące celem ataków były nie tylko budynkami przeznaczonymi na cele religijne, ale miały także znaczenie symboliczne i emocjonalne dla mieszkańców Timbuktu, ma znaczenie w określeniu poważnego charakteru popełnionej zbrodni ${ }^{56}$. Nie bez znaczenia dla Izby Orzekającej był fakt, iż dziewięć z 10 budynków zostało wpisanych na Listę Światowego Dziedzictwa UNESCO. Powołując się na autorytet listy, MTK uznał, że atak na obiekty na nią wpisane wydaje się być szczególnie poważny, jako że dotyczy nie tylko mieszkańców Timbuktu czy Mali, ale także całej społeczności międzynarodowej ${ }^{57}$. Przy ocenie ciężaru zbrodni MTK wziął także pod uwagę motywację sprawcy. Ponownie jednak akt oskarżenia sporządzony przez prokurator prezentuje znacznie szersze spectrum zbrodni popełnianej z motywów dyskryminacyjnych. Podczas gdy MTK jedynie przyznał, że motywacja ataku oparta na dyskryminacji religijnej ma znaczenie dla oceny wagi zbrodni, uznając, iż motyw ten bez wątpienia towarzyszył przywódcom Asnar Dine oraz Al Mahdiemu, prokurator przytoczyła m.in. wyrok Międzynarodowego Trybunału Karnego dla byłej Jugosławii (MTKJ) w sprawie Kordićia i Čerkeza. Uznał on wówczas, że:

celowe niszczenie obiektów religijnych, jeżeli dokonane z zamiarem dyskryminacji, stanowi atak na religijną tożsamość ludzi i jako takie może być oceniane jako zbrodnia przeciwko ludzkości. Cała ludzkość jest dotknięta zniszczeniem unikalnej kultury religijnej i towarzyszących jej obiektów. Tym samym, celowe zniszczenie obiektów poświęconych muzułmańskiej religii i edukacji, wraz z zamiarem dyskryminacji, może stanowić akt prześladowania $^{58}$.

56 Zob. tamże, par. 79.

57 Zob. tamże, par. 80.

58 International Criminal Court, Prosecutor v. Dario Kordić \& Mario Čerkez, IT-95-14/2-T, Judgement of 26 February 2001, par. 207: „This act, when perpetrated with the requisite discriminatory intent, amounts to an attack on the very religious identity of a people. As such, it manifests a nearly pure expression of the notion of «crimes against humanity", for all of humanity is indeed injured by the destruction of a unique religious culture and its concomitant cultural objects. The Trial Chamber therefore finds that the destruction and wilful damage of institutions dedicated to Muslim religion or education, coupled with the requisite discriminatory intent, may amount to an act of persecution". 
Jest to argument niezwykle istotny - zważywszy na kontekst sprawy Al Mahdiego oraz ewentualne przyszłe sprawy dotyczące niszczenia dziedzictwa podlegające jurysdykcji MTK - jednak nierozwinięty przez Izbę Orzekającą.

\section{Wnioski i uwagi autora}

Wiele ze współczesnych grup ekstremistycznych motywuje swoje działania chęcią zniszczenia kulturowej różnorodności i jej przejawów, które nie odpowiadają homogenicznej wersji świata religijnych bojowników, a eksterminacji mniejszości etnicznych i religijnych towarzyszy eliminacja wszelkich przejawów ich bytności na okupowanych obszarach ${ }^{59}$. Akty dewastacji dóbr kultury stały się modus operandi różnych grup ekstremistycznych, w ramach stosowanej przez nie polityki terroru, będąc współczesną wersją ikonoklazmu. Ikonoklazm, zwany też terroryzmem kulturowym, ma na celu zniszczenie wszystkiego, co według jego wyznawców stoi na drodze pomiędzy ludzkością a boskością ${ }^{60}$. Takie działania nazwane zostały przez Dyrektor Generalną UNESCO, I. Bokovą, mianem czystek kulturowych ${ }^{61}$. Jak wskazała w swoim raporcie z $2016 \mathrm{r}$. K. Bennoune - Specjalny Sprawozdawca ds. praw kulturalnych - celowe niszczenie dóbr oraz symboli religijnych czy kulturowych może być uznane za dowód zamiaru zniszczenia i eliminacji danej grupy w rozumieniu Konwencji w sprawie zapobiegania i karania zbrodni ludobójstwa ${ }^{62}$.

Projekt tejże konwencji, ostatecznie przyjętej przez ONZ w 1948 r., jako jeden z rodzajów ludobójstwa wymieniał ludobójstwo kulturowe ${ }^{63}$. Rafał Lemkin, który starania o przyjęcie konwencji rozpoczął jeszcze

59 Zob. S. Stryjkowska, Problematyka ochrony dziedzictwa..., s. 220.

60 Zob. J. Matusitz, Symbolism in Terrorism. Motivation, Communication, and Behavior, Lanham 2015, s. 49.

61 Zob. United Nations Educational, Scientific and Cultural Organization, Reinforcement of UNESCO's Action for the Protection of Culture and the Promotion of Cultural Pluralism in the Event of Armed Conflict, 38 C/49, 2 November 2015.

62 Zob. United Nations General Assembly. Human Rights Council, Report of the Special Rapporteur in the Field of Cultural Rights, A/HRC/31/59, 3 February 2016, par. 64.

63 Zob. H. Schreiber, Cultural genocide - ludobójstwo kulturowe - kulturobójstwo: niedokończony czy odrzucony projekt prawa międzynarodowego?, [w:] H. Schreiber, G. Michałowska 
przed wojną, w swojej pracy Acts of Vandalism, uznał, że „ataki wymierzone przeciwko danej grupie mogą także przybrać formę systematycznego i zorganizowanego niszczenia sztuki i dziedzictwa kulturowego, które jest wyrazem unikalnego geniuszu i osiągnięć danej grupy w dziedzinie nauki, sztuki czy literatury" ${ }^{\prime 64}$. Kulturowe ludobójstwo, według R. Lemkina, to polityka, która wykorzystując drastyczne metody, ma na celu szybkie i całkowite wyeliminowanie kulturalnego, moralnego czy religijnego życia danej społeczności. Może ono obejmować zakaz posługiwania się językiem charakterystycznym dla danej grupy, ograniczaniem możliwości wykonywania swoich tradycyjnych praktyk, niszczeniem miejsc i przedmiotów związanych z kultem religijnym, prześladowaniem duchownych oraz konfiskatę lub niszczenie skarbów narodowych, bibliotek, archiwów, muzeów czy galerii. Choć pojęcie kulturowego ludobójstwa, m.in. ze względu na jego konotacje z ochroną mniejszości i obawą państw przed możliwością ingerencji w ich sprawy wewnętrzne, nie zostało włączone do tekstu konwencji, jego rewizja może być pomocna przy stworzeniu efektywnych mechanizmów ochrony dziedzictwa kulturowego - nie tylko w jego materialnych, ale także niematerialnych przejawów. Należy zatem żałować, że MTK nie podjął próby głębszej analizy tego zjawiska przy okazji sprawy Al Mahdiego.

\section{Poglądy innych przedstawicieli nauki}

Sprawa Al Mahdiego jest pierwszą sprawą przed MTK, zaprzysiężonej w 2012 r. prokurator F. Bensoudy. Niewątpliwie wybór tej sprawy był wyborem ryzykownym - spotkał się zarówno z pozytywnym przyjęciem, jak i z falą krytyki. Prokurator zarzucano przede wszystkim, że niszczenie dziedzictwa kulturowego nie jest zbrodnią wojenną, jako że nie pociąga za sobą bezpośrednich ofiar ${ }^{65}$ oraz że MTK powinno zająć się sprawami

(red.), Kultura w stosunkach międzynarodowych, t. 1. Zwrot kulturowy, Warszawa 2013, s. 252-274.

64 P. Gerstenblith, The Destruction of Cultural Heritage..., s. 342.

65 Zob. J. Jones, Destroying Priceless Art is Vile and Offensive - But It is not a War Crime, "The Guardian" 22.08.2016, https://www.theguardian.com/artanddesign/jonathanjonesblog/2016/aug/22/ahmad-al-mahdi-war-crimes-the-hague-destroying-mausoleums-timbuktu [dostęp: 22.05.2018 r.]. 
naprawdę ważnymi, dotyczącymi ludobójstwa, tortur i gwałtów ${ }^{66}$. Odpowiedzią na tą krytykę wydaje się być posiedzenie, które miało miejsce dnia 4 kwietnia 2018 r. w siedzibie MTK. Na posiedzeniu tym Al Hassan Ag Abdoul Aziz Ag Mohamed Ag Mahmoud, będącemu głównodowodzącym Ansar Dine, przedstawiono zarzuty popełnienia między innymi zbrodni przeciwko ludzkości (w tym tortur, zgwałcenia, niewolnictwa seksualnego, prześladowania oraz innych nieludzkich czynów o podobnym charakterze) oraz zbrodni wojennych (w tym zamachów na godność osobistą, a w szczególności poniżające i upokarzające traktowanie; skazywanie i wykonywanie egzekucji bez uprzedniego wyroku, wydanego przez należycie ukonstytuowany sąd oraz zamierzone kierowanie ataków na budynki przeznaczone na cele religijne oraz pomniki historyczne) w związku z konfliktem w Mali ${ }^{67}$. Postawienie zarzutów Al Mahdiemu skrytykowała również M. Lostal $\mathrm{w}$ artykule The Misplaced Emphasis on the Intangible Dimension of Cultural Heritage in the Al Mahdi Case at ICC ${ }^{68}$, zarzucającą argumentacji prokurator krótkowzroczność, która w przyszłości może zaowocować brakiem możliwości osądzenia winnych ataków na dziedzictwo kulturowe. Marina Lostal oparła swoje twierdzenie na tezie, iż antropologiczne podejście zastosowane w akcie oskarżenia może nie być skuteczne w przypadku zniszczonego dziedzictwa, które w przeciwieństwie do dziedzictwa Timbuktu nie jest związane z żadną konkretną grupą czy społecznością i tym samym nie będzie stanowiło ataku na ich tożsamość kulturową. W tym względzie jednak należy pamiętać, że niszczenie dziedzictwa nie stanowi straty wyłącznie dla grup bezpośrednio związanych z danymi obiektami, lecz także stratę dla całej społeczności międzynarodowej, co podkreślała nie tylko prokurator, ale również Izba Orzekająca MTK w wyroku w sprawie Al Mahdiego, określając zakres spowodowanych szkód ${ }^{69}$. Co więcej, antropologiczne podejście do dziedzi-

66 Zob. B.I. Daniels, Is the Destruction of Cultural Property a War Crime?, "Apollo. The International Art Magazine" 28.11.2016, https://www.apollo-magazine.com/is-the-destruction-of-cultural-property-a-war-crime [dostęp: 22.05 .2018 r.].

67 Zob. Al Hassan Ag Abdoul Aziz Ag Mohamed Ag Mahmoud Makes First Appearance Before the ICC, https:/ / www.icc-cpi.int/Pages/item.aspx?name=pr1377 [dostęp: 22.05.2018 r.].

68 M. Lostal, The Misplaced Emphasis on the Intangible Dimension of Cultural Heritage in the Al Mahdi Case at ICC, "Inter Gentes - The McGill Journal of International Law \& Legal Pluralism" 2017, t. 1, nr 2, s. 45-58.

69 Zob. International Criminal Court, Prosecutor v. Ahmad Al Faqi Al Mahdi, ICC01/12-01/15, Judgement and Sentence (public), 27 September 2016, par. 80. 
ctwa kulturowego, które zastosowała prokurator w sprawie Al Mahdiego, jest odzwierciedleniem zmian, jakie zaszły $w$ prawie międzynarodowym na przestrzeni ostatnich lat. Obecnie nie budzi wątpliwości fakt, że dziedzictwo kulturowe jest ważne nie tylko samo w sobie, ale także w relacji z jego "ludzkim" wymiarem, zważywszy na znaczenie, jakie odgrywa ono dla poszczególnych jednostek oraz całych społeczności, stanowiąc nieodłączną część ich tożsamości. Jednym z najczęściej przywoływanych argumentów przemawiających za koniecznością ochrony dziedzictwa jest jego głęboki związek z ludzką tożsamością. Zważywszy zaś, że tożsamość jest głównym elementem definiującym jednostki, będąc silnie związana z poczuciem ludzkiej godności, jej ochrona jest podstawowym celem praw człowieka. Patrząc więc z tej perspektywy na dziedzictwo kulturowe, jego związek z prawami człowieka rysuje się wyraźnie, a tym samym jego ochrona jest głęboko powiązana z ochroną praw człowieka ${ }^{70}$. Stąd też meritum sprawy Al Mahdiego nie stanowi zniszczenie zabytków Timbuktu per se, ale atak na kulturową tożsamość zarówno lokalnej społeczności bezpośrednio związanej z owymi zabytkami, jak i zubożenie dziedzictwa kulturowego całej ludzkości.

\section{Podsumowanie}

Międzynarodowa ochrona dziedzictwa kulturowego przeszła w ostatnich latach znaczącą ewolucję. Nastąpiło przede wszystkim przejście od ochrony wąsko pojmowanego dobra kultury do kompleksowego systemu ochrony dziedzictwa kulturowego, zarówno w czasach konfliktu zbrojnego, jak i w czasach pokoju. Współcześnie kultura w prawie międzynarodowym rozumiana jest jako pewien proces, $w$ którym jednostki i społeczności, zachowując swoje cechy charakterystyczne, dają wyraz kulturze ludzkości, przejawiającej się między innymi w sposobach życia, języku, ustnej czy pisanej literaturze, rytuałach, ceremoniach i związanych z nimi artefaktami. Owo postrzeganie kultury odzwierciedlone zostało w argumentacji prokurator MTK w sprawie Al Mahdiego, jako że dotyczyła ona dwóch aspektów dziedzictwa kulturowego - jego materialnej, jak i niematerialnej formy - nierozerwalnie związanych z prawami

\footnotetext{
70 Zob. L. Lixinski, Intangible Cultural Heritage in International Law, Oxford 2013, s. 146.
} 
człowieka i ludzką godnością. Niewątpliwie wyrok w sprawie Al Mahdiego jest orzeczeniem precedensowym. Choć MTK nie w pełni wykorzystał możliwości, jakie stwarzała sprawa zniszczenia dziedzictwa kulturowego Timbuktu, a sam akt oskarżenia prezentuje pod tym względem znacznie celniejsze argumenty, to jednak fakt, iż sprawa zniszczenia obiektów kulturalnych stała się przedmiotem analizy Międzynarodowego Trybunału Karnego, należy przyjąć z aprobatą i z nadzieją, że również kolejni sprawcy ataków na dziedzictwo kulturowe zostaną w przyszłości pociągnięci do odpowiedzialności.

Słowa kluczowe: Międzynarodowy Trybunał Karny, UNESCO, Timbuktu, dziedzictwo kultury, prawa człowieka, kulturowe czystki

\section{Bibliografia}

\section{Źródła}

\section{Akty prawne}

Konwencja dotycząca praw i zwyczajów wojny lądowej [IV konwencja haska], Haga, 18 października 1907 r., Dz. U. z 1927 r. Nr 21, poz. 161.

Konwencja o ochronie dóbr kulturalnych w razie konfliktu zbrojnego wraz z Regulaminem wykonawczym do tej Konwencji oraz Protokół o ochronie dóbr kulturalnych $w$ razie konfliktu zbrojnego, podpisane w Hadze dnia 14 maja 1954 r., Dz. U. z 1957 r. Nr 46, poz. 212, zał.

Międzynarodowy Pakt Praw Gospodarczych, Społecznych i Kulturalnych otwarty do podpisu w Nowym Jorku dnia 19 grudnia 1966 r., Dz. U. z 1977 r. Nr 38, poz. 169.

Konwencja w sprawie ochrony światowego dziedzictwa kulturalnego i naturalnego, przyjęta w Paryżu dnia 16 listopada 1972 r. przez Konferencję Generalną Organizacji Narodów Zjednoczonych dla Wychowania, Nauki i Kultury na jej siedemnastej sesji, Dz. U. z 1976 r. Nr 32, poz. 190.

Rzymski Statut Międzynarodowego Trybunału Karnego, sporządzony w Rzymie dnia 17 lipca 1998 r., Dz. U. z 2003 r. Nr 78, poz. 708.

Drugi Protokół do Konwencji o ochronie dóbr kulturalnych w razie konfliktu zbrojnego, podpisanej w Hadze dnia 14 maja 1954 r., sporządzony w Hadze dnia 26 marca 1999 r., Dz. U. z 2012 r. poz. 248. 
Konwencja UNESCO w sprawie ochrony niematerialnego dziedzictwa kulturowego, sporządzona w Paryżu dnia 17 października 2003 r., Dz. U. z 2011 r. Nr 172, poz. 1018.

United Nations Economic and Social Counsil. Committee on Economic, Social and Cultural Rights, General Comment No. 21. Right of Everyone to Take Part in Cultural Life (art. 15, par. 1(a) of the International Covenant on Economic, Social and Cultural Rights), 21 December 2009, E/C.12/GC/21, https:/ / www.refworld.org/docid/4ed35bae2.html [dostęp: 3.02.2020 r.].

United Nations General Assembly. Human Rights Council, Report of the Special Rapporteur in the Field of Cultural Rights, 3 February 2016, A/HRC/31/59, https://www.ohchr.org/en/hrbodies/hrc/regularsessions/session31/ documents/a.hrc.31.59_e.docx [dostęp: 3.02.2020 r.].

United Nations Educational, Scientific and Cultural Organization, Recommendation on Participation by the People at Large in Cultural Life and tTheir Contribution to It, 26 November 1976, http:/ / portal.unesco.org/en/ev.php-URL_ID=13097\&URL_ DO=DO_TOPIC\&URL_SECTION=201.html [dostęp: 3.02.2020 r.].

UNESCO Universal Declaration on Cultural Diversity, 2 November 2001, http:/ / portal.unesco.org/en/ev.php-URL_ID=13179\&URL_DO=DO_ TOPIC\&URL_SECTION=201.html [dostęp: 3.02.2020 r.].

UNESCO Declaration Concerning the Intentional Destruction of Cultural Heritage, 17 October 2003 [Records of General Conference, 32 ${ }^{\text {nd }}$ Session, Paris 2003], http:/ / portal.unesco.org/en/ev.php-URL_ID=17718\&URL_DO=DO_TOPIC\&URL_ SECTION=201.html [dostęp: 3.02.2020 r.].

United Nations Educational, Scientific and Cultural Organization, Reinforcement of UNESCO's Action for the Protection of Culture and the Promotion of Cultural Pluralism in the Event of Armed Conflict, 38 C/49, 2 November 2015, https:/ / unesdoc.unesco.org/ark:/48223/pf0000235186 [dostęp: 3.02.2020 r.].

Rezolucja Parlamentu Europejskiego z dnia 30 kwietnia 2015 r. w sprawie niszczenia zabytków kultury przez ISIS/Daisz (2015/2649(RSP), Dz. Urz. UE C 346 z 21.09.2016, s. 55-59.

\section{Orzecznictwo}

United Nations International Criminal Tribunal for the former Yugoslavia, Prosecutor v. Dario Kordić \& Mario Čerkez, No IT-95-14/2-T, Judgement of 26 February 2001, https://www.icty.org/en/case/kordic_cerkez [dostęp: 3.02.2020 r.].

United Nations International Criminal Tribunal for the former Yugoslavia, Prosecutor v. Miodrag Jokić, No IT-01-42/1-S, Judgement of 18 March 2004, https:/ / www.icty.org/en/case/miodrag_jokic [dostęp: 3.02.2020 r.].

International Criminal Court, Prosecutor v. Ahmad al Faqi al Mahdi, No ICC01/12-01/15 [public redacted version of "Prosecution's submissions on 
sentencing" in the Al Mahdi case], 22 July 2016, https:/ / www.icc-cpi.int/CourtRecords/CR2016_07244.PDF [dostęp: 3.02.2020 r.].

International Criminal Court, Prosecutor v. Ahmad Al Faqi Al Mahdi, No ICC01/12-01/15, Judgement and Sentence (public), 27 September 2016, https: // www.icc-cpi.int/CourtRecords/CR2016_07244.PDF [dostęp: 3.02.2020 r.].

\section{Literatura}

Al Hassan Ag Abdoul Aziz Ag Mohamed Ag Mahmoud Makes First Appearance Before the ICC, https:/ / www.icc-cpi.int/Pages/item.aspx?name=pr1377 [dostęp: 22.05.2018 r.].

Bugnion F., The Origins and Development of the Legal Protection of Cultural Property in the Event of Armed Conflict. 50 ${ }^{\text {th }}$ Anniversary of the 1954 Hague Convention for the Protection of Cultural Property in the Event of Armed Conflict, International Committee of the Red Cross, https://www.icrc.org/en/doc/resources/documents/article/other/65shtj.htm [dostęp: 20.05.2018 r.].

Daniels B.I., Is the Destruction of Cultural Property a War Crime?, "Apollo. The International Art Magazine" 28.11.2016, https://www.apollo-magazine.com/ is-the-destruction-of-cultural-property-a-war-crime [dostęp: $22.05 .2018 \mathrm{r}$.].

Fincham D., Intentional Destruction and Spoliation of Cultural Heritage under International Criminal Law, „U.C. Davis Journal of International Law \& Policy” 2017, https://jilp.law.ucdavis.edu/issues/volume-23-2/jilp-23-2-Fincham.pdf [dostęp: 22.05.2018 r.].

Francioni F., F. Lenzerini, The 1972 World Heritage Convention. A Commentary, Oxford 2008.

Gerstenblith P., The Destruction of Cultural Heritage: A Crime Against Property or a Crime Against People?, „The John Marshall Review of Intellectual Property Law” 2016.

Henckaerts J.M., New Rules for the Protection of Cultural Property in Armed Conflict, „International Review of the Red Cross” 1999, nr 835.

Hodder I., Cultural Heritage Rights: From Ownership and Descent to Justice and Well-being, "Anthropological Quarterly" 2010, t. 83, nr 4.

Jones J., Destroying Priceless Art is Vile and Offensive - But it is Not a War Crime, "The Guardian" 22.08.2016, https://www.theguardian.com/artanddesign/ jonathanjonesblog/2016/aug/22/ahmad-al-mahdi-war-crimes-the-hague-destroying-mausoleums-timbuktu [dostęp: 22.05.2018 r.].

Kubiak K., Konflikt w Mali. Rebelia Tuaregów, islamiści i międzynarodowa interwencja, „Przegląd Politologiczny” 2014, nr 1.

Lixinski L., Intangible Cultural Heritage in International Law, Oxford 2013.

Lostal M., The Misplaced Emphasis on the Intangible Dimension of Cultural Heritage in the Al Mahdi Case at ICC, „Inter Gentes - The McGill Journal of International Law \& Legal Pluralism" 2017, t. 1, nr 2. 
Matusitz J., Symbolism in Terrorism. Motivation, Communication, and Behavior, Lanham 2015.

Mikos-Skuza E., K. Sałaciński (red.), Ochrona dziedzictwa kultury w czasie konfliktów zbrojnych w świetle prawa międzynarodowego i krajowego. 60-lecie konwencji haskiej i 15-lecie jej Protokotu II, Warszawa 2015.

Nahlik S.E., Grabież dzieł sztuki. Rodowód zbrodni międzynarodowej, Wrocław 1958.

Nieć H., Ojczyzna dzieła sztuki. Międzynarodowa ochrona integralności narodowej spuścizny kulturalnej, Kraków 1980.

Przyborowska-Klimczak A., Międzynarodowa Ochrona Niematerialnego Dziedzictwa Kulturalnego, „Problemy Współczesnego Prawa Międzynarodowego, Europejskiego i Porównawczego" 2005, t. 3.

Przyborowska-Klimczak A., Rozwój ochrony dziedzictwa kulturalnego w prawie międzynarodowym na przełomie XX i XXI wieku, Lublin 2011.

Stryjkowska S., Problematyka ochrony dziedzictwa kulturowego w działalności międzynarodowych trybunatów karnych, „Przegląd Prawniczy Uniwersytetu im. Adama Mickiewicza" 2016, t. 6.

United Nations Economic and Social Council, Committee on Economic, Social and Cultural Rights, Cultural Life in the Context of Human Rights. Background Paper Submitted by Ms. Yvonne Donders, 9 May 2008, E/C.12/40/13, https:/ / www.scribd.com/document/120158385/Donders-Cultural-Life-in-the-Context-of-Human-Rights [dostęp: 3.02.2020 r.].

Wierczyńska K., A. Jakubowski, Zbrodnie przeciwko dziedzictwu kulturowemu przed Międzynarodowym Trybunałem Karnym - analiza krytyczna, "Studia Prawnicze" 2016, z. 1.

Vrdoljak A., The Cultural Dimension of Human Rights, Oxford 2013.

Schreiber H., Cultural genocide - ludobójstwo kulturowe - kulturobójstwo: niedokończony czy odrzucony projekt prawa międzynarodowego?, [w:] H. Schreiber, G. Michałowska (red.), Kultura w stosunkach międzynarodowych, t. 1. Zwrot kulturowy, Warszawa 2013.

Schreiber H., Konwencja o ochronie dóbr kulturalnych w razie konfliktu zbrojnego wraz $z$ Regulaminem wykonawczym do tej Konwencji oraz Protokół o ochronie dóbr kulturalnych w razie konfliktu zbrojnego podpisane w Hadze dnia 14 maja 1954 r., [w:] K. Zalasińska (red.), Konwencje UNESCO w dziedzinie kultury. Komentarz, Warszawa 2014.

Zeidler K. (red), Leksykon prawa ochrony zabytków. 100 podstawowych pojęć, Warszawa 2010. 


\section{AL MAHDI CASE AT THE INTERNATIONAL CRIMINAL COURT: LANDMARK DECISION OR MISSED PPPORTUNITY?}

\section{Sum mary}

The case of Al Mahdi in the International Criminal Court is a landmark case, though being a controversial one. On 27of September 2016 the ICC for the first time issued a judgement concerning the war crime of intentionally directing attacks against buildings dedicated to religion, education, art, science or historic monuments, provided they are not military objectives. The case of Al Mahdi is a starting point for the historical analysis of the notion of culture in the international law - from the cultural property, protected in the times of armed conflicts, through cultural heritage in its tangible form, to intangible heritage. By understanding culture as dynamic and pivotal for local societies, as well as for international community, cultural heritage is now being perceived as an important part of human dignity and thus human rights.

Key words: International Criminal Court, UNESCO, Timbuktu, cultural heritage, human rights, cultural cleansing

\section{ДЕЛО АЛЬ-МАХДИ В МЕЖДУНАРОДНОМ УГОЛОВНОМ СУДЕ: ЗНАМЕНАТЕЛЬНЫЙ ПРИГОВОР ИЛИ УПУЩЕННАЯ ВОЗМОЖНОСТЬ?}

\section{Резюме}

Дело Аль-Махди в Международном уголовном суде является революционным, но не лишенным противоречий. 27 сентября 2016 года Международный уголовный суд впервые в истории вынес решение о военном преступлении, заключающемся в преднамеренном нападении на здания, предназначенные для религиозных, образовательных, художественных, научных целей или исторических памятников, при условии, что они не являются военными целями, ссылаясь тем самым на ст. 8, п. 2 (e) (iv) Римского статута. Дело Аль-Махди является отправной точкой для исторического анализа важности культуры и ее защиты в международном праве - от узко воспринимаемого предмета защиты в форме культурных ценностей во времена вооруженных конфликтов, до защиты культурного наследия в его материальном выражении и до защиты нематериального наследия. Современное понимание культуры как живого творения и восприятие важности, которую культура и наследие играют как для местных общин, так и для международного сообщества, делают наследие важным элементом человеческого достоинства и, следовательно, прав человека.

Ключевые слова: Международный уголовный суд, ЮНЕСКО, Тимбукту, культурное наследие, права человека, культурные чистки. 